\author{
ANNA HNATYSZYN-DZIKOWSKA* \\ SŁAWOMIR ZWIERZCHLEWSKI
}

\title{
STABILIZACYJNA FUNKCJA PAŃSTWA W WARUNKACH MIĘDZYNARODOWEJ INTEGRACJI GOSPODARCZEJ - RYS HISTORYCZNY
}

\begin{abstract}
WSTĘP
Dyskusja nad procesem międzynarodowej integracji gospodarczej nabiera w ostatnich latach szczególnego znaczenia. Coraz szerszy zasięg tej integracji skłania do podjęcia studiów i badań na różnymi aspektami tzw. procesów scaleniowych. Jednym $\mathrm{z}$ takich aspektów jest rola państwa $\mathrm{w}$ gospodarce $\mathrm{w}$ warunkach integracji, głównie w kontekście współzależności sfery państwowej i ponadnarodowej. Na tym tle powstaje szereg problemów. Uczestnicy procesów integracyjnych muszą liczyć się z wymiernymi kosztami, przede wszystkim z częściową utratą suwerenności w posługiwaniu się instrumentami gospodarczymi. Skala utraty tej suwerenności zależy od zakresu i przyjętej formy integracji gospodarczej. Przekazywanie kompetencji (w obszarze instrumentarium gospodarczego) na szczebel ponadnarodowy znacznie modyfikuje sposób wyznaczania polityki stabilizacyjnej w państwach, które tworzą dane ugrupowanie integracyjne. Stopień modyfikacji polityki, zwłaszcza fiskalnej i pieniężnej, uzależniony jest od rozwiązań instytucjonalnych ustalonych $\mathrm{w}$ procesie integracyjnym, w tym w dużej mierze od tego, czy wypracowano zasadę koordynacji, czy unifikacji (centralizacji) poszczególnych polityk ekonomicznych.

Celem niniejszego opracowania jest przegląd teoretycznego dorobku z zakresu problematyki suwerenności polityki gospodarczej w warunkach integracji oraz

\footnotetext{
* Adiunkt, Katedra Zdrowia Publicznego, Collegium Medicum, Uniwersytet Mikołaja Ko-

** Adiunkt, Katedra Polityki Gospodarczej i Samorządowej, Uniwersytet Ekonomiczny w Po-
} pernika w Toruniu. znaniu.
\end{abstract}


ukazanie faktycznych dylematów w obszarze polityki stabilizacyjnej, które zaistniały w systemach integracyjnych funkcjonujących w XX wieku.

\section{KRÓTKI PRZEGLĄD DEFINICJI INTEGRACJ GOSPODARCZEJ}

Integracja gospodarcza (integracja ekonomiczna) jest pojęciem wielopłaszczyznowym, obejmującym sferę życia ekonomicznego, jak i społecznego - politycznego. $\mathrm{Z}$ reguły pojęcie to jest stosowane w odniesieniu do integracji całych gospodarek w ujęciu międzynarodowym, przede wszystkim w zakresie swobody przemieszczania się produktów i czynników wytwórczych oraz scalania różnych obszarów polityki. W literaturze przedmiotu nie występuje jedna, powszechnie akceptowana definicja integracji gospodarczej ${ }^{1}$. Najczęściej jednak definicje te grupuje się w obszarach dwóch nurtów. Pierwszy traktuje integrację jedynie jako formę współpracy gospodarczej. Drugi postrzega ją jako zupełnie nową jakość ekonomiczną. Można w tym miejscu przytoczyć wybrane definicje integracji gospodarczej będące wyrazem poglądów przedstawicieli powyższych nurtów.

Zgodnie z pierwszym nurtem, integrację gospodarczą definiuje się jako zbliżanie procesów gospodarczych wewnątrz ugrupowania integracyjnego do procesów, które zachodzą na poziomie poszczególnych krajów należących do danego ugrupowania ${ }^{2}$. Tak sformułowana definicja sugeruje, że podstawą procesu integracyjnego jest swobodny przepływ dóbr, usług, kapitału i siły roboczej, ponieważ czynniki te swobodnie przemieszczają się (z założenia) wewnątrz poszczególnych państw ${ }^{3}$. Kwestią dyskusyjną jest zakres integracji polityk gospodarczych. Zgodnie z omawianą definicją, wyznaczanie np. scentralizowanej polityki pieniężnej czy polityki fiskalnej w ramach całego ugrupowania powinno być zbliżone do sposobu prowadzenia tych polityk w pojedynczych państwach tworzących obszar integracyjny w zależności od różnych uwarunkowań, np. aktualnego stanu koniunktury. Taka sytuacja nie wydaje się możliwa. Różnorodność uwarunkowań ekonomicznych $\mathrm{w}$ krajach tworzących dane ugrupowanie integracyjne wyklucza raczej stosowanie jednej, ponadnarodowej polityki pieniężnej czy fiskalnej, którą wszystkie kraje tego ugrupowania uznałyby za odpowiednią z ich punktu widzenia ${ }^{4}$. Inny przedstawi-

1 Przegląd teoretycznych koncepcji integracji gospodarczej zob. m.in. B. Balassa, The Theory of Economic Integration, Allen \& Unwin, London 1962, s. 1-9; P. Robson, The Economics of International Integration, Allen \& Unwin, London 1987, s. 17-25; S. Lis, S. Miklaszewski, Kraje europejskie wobec wspótczesnych procesów integracyjnych, Wydawnictwo i Drukarnia „Secesja”, Kraków 1993, s. 7-25.

2 A. Aron, Problems of European Integration, „Lloyds Bank Review” 1953, no. 28, s. 1-3.

S. Lis, S. Miklaszewski, op. cit., s. 7.

4 Należy zauważyć, iż nawet bardzo zbliżone uwarunkowania ekonomiczne w krajach tworzących dane ugrupowanie integracyjne nie muszą oznaczać, że ponadnarodowa polityka pieniężna czy fiskalna byłaby odpowiednia $\mathrm{z}$ punktu widzenia wszystkich państw. 
ciel omawianego nurtu definiuje integrację jako proces prowadzący do większego stopnia unifikacji ${ }^{5}$. W zaprezentowanej definicji powstaje problem terminologiczny. Trudno jednoznacznie rozstrzygnąć, co oznacza pojęcie „większy stopień unifikacji”. Należy jedynie założyć, że można je utożsamiać z większym poziomem koordynacji. Niezależnie od wskazanego problemu terminologicznego, omawiana definicja nie precyzuje, jakie dziedziny gospodarki powinny być objęte przez procesy integracyjne $\mathrm{w}$ celu ich większej unifikacji (większej koordynacji). Można więc przyjąć, że tymi dziedzinami są zarówno rynki, jak i poszczególne polityki. Zgodnie $\mathrm{z}$ innym podejściem $\mathrm{w}$ ramach prezentowanego nurtu, integracją ekonomiczną określa się łączenie dwóch lub więcej jednostek ekonomicznych w pewną

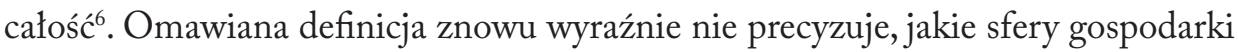
powinny się łączyć w całość, aby zachodził proces integracji ekonomicznej. $Z$ tego względu przedstawiana definicja koresponduje z definicją poprzednią. Należy bowiem założyć, iż dane ugrupowanie integracyjne będzie stanowić całość w sytuacji, kiedy zintegrowane zostaną nie tylko rynki, ale również przynajmniej podstawowe instrumenty polityki gospodarczej.

Zaznaczono wcześniej, że drugi nurt prezentowanej koncepcji postrzega integrację jako proces tworzenia całkowicie nowej jakości. Oznacza to, iż w miejsce dotychczasowej struktury gospodarczej powstaje nowa struktura o zupełnie odmiennych właściwościach. Najwybitniejszy przedstawiciel tego nurtu - B. Balassa ujmuje integrację jako proces znoszenia barier między gospodarkami różnych krajów, co ma doprowadzić do stanu, w którym zaniknie jakakolwiek forma dyskryminacji między podmiotami gospodarczymi ${ }^{7}$. Odwołuje się przy tym do różnych stopni zaawansowania tego procesu. W przypadku unii celnej znoszenie wskazanych barier polega na ograniczaniu lub całkowitej eliminacji stosowania polityki protekcjonistycznej. W przypadku wspólnego rynku znoszenie barier oznacza nie tylko integrację rynku towarowego, ale także stworzenie warunków do swobodnego przepływu czynników wytwórczych. B. Balassa zauważa, że bardziej rozwinięte obszary integracyjne (w odniesieniu do unii celnej i wspólnego rynku) wymagają harmonizacji głównych polityk ekonomicznych, ale również harmonizacji polityki prawnej i standaryzacyjnej. ${ }^{8}$ Zgodnie z kolejnym stanowiskiem, integracja to proces polegający na przeobrażeniu struktur drogą polityki

5 F. Machlup, Integracja gospodarcza - narodziny i rozwój idei, Państwowe Wydawnictwo Naukowe, Warszawa 1986, s. 34.

6 H. G. Grubel, International Economics, Irwin, Homewood, Illinois 1981, s. 41.

B. Balassa, op. cit., s. 1.

8 Wynika $z$ tego, że dla B. Balassy barierami występującymi między gospodarkami różnych krajów jest nie tylko brak całkowitej swobody w przepływie dóbr, usług, kapitału i pracy, ale również różnokierunkowe wyznaczanie poszczególnych polityk. 
gospodarczej, której efektem jest koordynacja i unifikacja ${ }^{9}$. Trudno jednoznacznie wyjaśnić, na czym ma polegać przeobrażenie struktur drogą polityki gospodarczej. Jeżeli jednak działania te mają doprowadzić do koordynacji i unifikacji (struktur gospodarczych w integrujących się krajach), to można uznać, że powinny dotyczyć zarówno rynków, jak i polityk. Następny przedstawiciel omawianego nurtu twierdzi, że integracja gospodarcza zachodzi tylko wtedy, kiedy wyznaczaniem polityki gospodarczej w państwach członkowskich zajmuje się ponadnarodowe centrum ${ }^{10}$. Oznacza to de facto powołanie ponadnarodowej władzy ustawodawczej, wykonawczej oraz pieniężnej. Oczywistym następstwem funkcjonowania ponadnarodowej władzy jest również pełna liberalizacja rynków. Zaprezentowana definicja jest więc najdalej posuniętym ujęciem integracji. Można wysunąć wniosek, iż istotą integracji jest tutaj wykształcenie, w ramach danego obszaru integracyjnego, struktury podobnej do federalizmu.

Wydaje się, że definicje zaprezentowane w ramach pierwszego i drugiego nurtu nie odzwierciedlają wyraźnie różnic w podejściach do integracji gospodarczej. Wynika to $z$ dwóch przyczyn. Po pierwsze, różnie można interpretować pojęcie „zupełnie nowa jakość ekonomiczna” będące podstawą wyodrębnienia drugiego nurtu. Termin ten może odnosić się do wykształcenia nowej struktury produkcji, nowych instrumentów polityki gospodarczej czy nowego układu instytucji na danym terytorium integracyjnym. Po drugie, podstawą procesu integracyjnego są różne formy współpracy gospodarczej pomiędzy łączącymi się państwami. Jeżeli więc można stworzyć, w ramach tego procesu, całkowicie nową jakość ekonomiczną, to musi ona opierać się na szerokiej współpracy między krajami. Należy zauważyć, że taka wspólpraca jest szczególnie wymagana przy tworzeniu np. nowego instrumentarium polityki gospodarczej czy nowych instytucji. Konstruowanie nowych instrumentów i/lub instytucji na danym obszarze integracyjnym może z kolei stanowić podstawę do uznania, że kształtuje się w jego granicach nowa jakość ekonomiczna. W ten sposób praktycznie zanikają kryteria wyodrębnienia dwóch powyższych nurtów.

Należy zaznaczyć, że międzynarodowa integracja gospodarcza (bez względu na jej zakres pojęciowy) tworzy zasadniczy problem, który dotyczy kwestii suwerenności polityki ekonomicznej oraz możliwości zastosowania gospodarczych narzędzi stabilizacyjnych. Niezależnie bowiem od zakresu integracji, wymaga ona od poszczególnych państw swoistego podporządkowania w stosunku do ugrupowania integracyjnego ogółem. Skrajnym przejawem takiego podporządkowania jest utrata autonomii w wyznaczaniu pewnych dziedzin polityki gospodarczej.

\footnotetext{
9 A. J. Marques-Mendes, Economic Integration and Growth in Europe, Croom Helm, London 1986, s. 16 .

10 J.Tinbergen, International Economic Integration, Elsevier, Amsterdam 1954, s. 95-96.
} 


\section{SUWERENNOŚĆ POLITYKI GOSPODARCZEJ W WARUNKACH INTEGRACJI}

Problematyka ewolucji roli państwa w gospodarce jest ściśle związana z definiowaniem suwerenności ${ }^{11}$. Gros publikacji odnoszących się do kwestii suwerenności dotyczy problemu interpretacji i ewolucji pojęcia z punktu widzenia nauk politologicznych ${ }^{12}$. W literaturze ekonomicznej wskazuje się, iż miejsce suwerenności monistycznej - wyłącznej - stopniowo zajmuje suwerenność pluralistyczna, wielopodmiotowa i obejmująca różne układy współpracy ${ }^{13}$. Suwerenność państwa zaczęto ujmować w sposób funkcjonalny, tzn. akcentujący nie tyle wyjątkowy status i niezależność państwa wobec innych, ile raczej jego zdolność efektywnego wypełniania funkcji państwowych we współczesnym świecie. Istota suwerenności państwa była różnie pojmowana w procesie rozwoju gospodarczego. Począwszy od XVI w., termin ten przyjmował wiele różnych znaczeń. Stąd definiowanie suwerenności, jednoznaczne wskazanie jej atrybutów, konsekwencje, wreszcie kwestia nabycia i utraty budzą liczne spory. Prawo międzynarodowe ich nie rozstrzyga, ponieważ suwerenność nie stanowi przedmiotu wystarczająco jednoznacznych unormowań traktatowych ${ }^{14}$. W podstawowym znaczeniu, jak stwierdza L. Antonowicz, suwerenność jest nieodłączną i wyróżniającą cechą państwa ${ }^{15}$. Definiuje się ją jako społecznie rozpoznawalne prawo do sprawowania władzy w sposób samodzielny, niezależny od decyzji innych państw, przy zastrzeżeniu zgodności z prawem międzynarodowym ${ }^{16}$. Po raz pierwszy logiczną i spójną koncepcję suwerenności przedstawił w 1576 r. J. Bodin w Sześciu ksieggach o Rzeczpospolitej. $Z$ obserwacji polityki europejskiej wyprowadził wniosek, iż byt państwa, zależny od uwarunkowań międzynarodowych i od sytuacji wewnętrznej, jest zmienny

11 Szersze opracowanie w: A. Hnatyszyn-Dzikowska, Realizacja stabilizacyjnej funkcji państwa w warunkach europejskiej integracji gospodarczej, Wyd. PWSZ w Pile, Piła 2009, s. 35-49.

12 Por. S. Bieleń, Suwerenność pañstw i integracja europejska - wptywy i zależności, [w:] G. Michałowska (red.), Integracja europejska - Instytucje - Polityka - Prawo, Warszawa 2003, s. 40.

13 Patrz szerzej: J. Woś, A. Hnatyszyn-Dzikowska, Koncepcje suwerenności państwa w sferze polityki gospodarczej w warunkach europejskiej integracji gospodarczej, „Ruch Prawniczy, Ekonomiczny i Socjologiczny" 2007, z. 1, s. 173-181; A. Kukliński, O przysztości państwa, [w:] Przysztość państwa a gospodarka: studia nad możliwymi kierunkami zmian roli państwa w gospodarce w przysztości, Polska Akademia Nauk, Komitet Prognoz „Polska w XXI wieku”, Wyd. Elipsa, Warszawa 1997, s. 109.

14 I. Gawłowicz, Nowe wykorzystywanie suwerenności jako signum temporis, [w:] I. Gawłowicz, I. Wierzchowiecka (red.), Koncepcje suwerenności: zbiór studiów, Wyd. LexisNexis, Warszawa 2005, s. 26.

15 L. Antonowicz, Pojęcie pañstwa w prawie międzynarodowym, Wyd. PWN, Warszawa 1974, s. 138.

$16 \mathrm{~J}$. Caporaso, The European Union and Forms of State: Westpahalian, Regulatory or Post-Modern?, „Journal of Common Market Studies” 1996, no. 1, s. 35. 
i niepewny ${ }^{17}$. Jako niezbywalne atrybuty suwerenności wymieniał: stanowienie prawa, decydowanie o wojnie i pokoju, powoływanie najwyższych urzędników, rozstrzyganie sporów i prawo łaski, bicie monety, nakładanie podatków, określanie języka państwowego ${ }^{18}$. Twierdził, że najwyższa władza w państwie musi tkwić w jednym miejscu: stąd $z$ definicji suwerenność nie może być podzielona.

Po odrzuceniu rozwiniętej przez J. Bodina doktryny suwerenności absolutnej, najwyższej i niepodzielnej państwa, suwerenność zaczęto utożsamiać z pewną sumą kompetencji, w które wyposażone są trzy główne organy władzy państwowej. W odniesieniu do każdej z tych władz suwerenność musi być inaczej definiowana, choć wspólnym mianownikiem jest posiadanie jakiegoś uprawnienia ${ }^{19}$. O. Waever utrzymuje przy tym, że nie ma danej a priori listy cech, które określają suwerenność ${ }^{20}$. Suwerenność jest więc formą, której treść zmienia się w czasie ${ }^{21}$. Obecnie można przytoczyć szereg definicji suwerenności (por. tab. 1).

Tabela 1. Współczesne definicje suwerenności państwa

\begin{tabular}{|l|l|}
\hline \multicolumn{1}{|c|}{ Autor } & \multicolumn{1}{c|}{ DeflnIIJA } \\
\hline S. Bieleń & - suwerenność oznacza przede wszystkim równość praw i dobrowolność zaciągania zobowiązań \\
\hline J. Krantz & $\begin{array}{l}\text { - suwerenność definiuje przez zakres i charakter kompetencji państwowych oraz sposób ich wykony- } \\
\text { wania }\end{array}$ \\
\hline R. 0. Keohane & $\begin{array}{l}\text { - suwerenność oznacza zarówno wewnętrzną supremację nad wszystkimi innymi władzami na danym } \\
\text { terytorium, jak i zewnętrzną niezależność od innych podmiotów prawa międzynarodowego }\end{array}$ \\
\hline J. Czaputowicz & $\begin{array}{l}\text { - suwerenność rozumiana jest jako cecha państw i dotyczy efektywnego sprawowania władzy oraz swo- } \\
\text { body realizacji własnego interesu (znaczenie partykularystyczne), }\end{array}$ \\
\hline $\begin{array}{l}\text { suwerenność rozumiana jest jako zasada organizacyjna stosunków międzynarodowych (znaczenie uni- } \\
\text { wersalistyczne) }\end{array}$ \\
\hline
\end{tabular}

17 Por. J. Bodin, Sześć ksiag o Rzeczpospolitej, tłum. Z. Izdebski, Warszawa 1959, s. 88; cytat za: I. Wierzchowiecka, Suwerennośc państwowa w prawie międzynarodowym, [w:] I. Gawłowicz, I. Wierzchowiecka (red.), Koncepcje suwerenności..., s. 143.

18 J. Czaputowicz, Rola pañstwa w Unii Europejskiej, Centrum Europejskie Natolin, EUI Research Laboratory, z. 11, Warszawa 2004, s. 24.

19 A. Marszałek (red.), Integracja europejska: podręcznik akademicki, Wyd. PWE, Warszawa 2004, s. 314.

20 Szerzej: O. Waever, Identity, Integration and Security: Solving the Sovereignty Puzzle in E.U., „Journal of International Affairs” 1995, vol. 48, no. 2, s. 389-431.

${ }^{21} \mathrm{Na}$ przykład w traktacie westfalskim suwerenność obejmowała zdolność do decydowania o religii poddanych. Gdy religia przestała być atrybutem suwerenności, to nie wpłynęło to na postrzeganie państwa jako podmiotu mniej suwerennego. J. Czaputowicz, Rola państwa..., s. 17. 
Ciąg dalszy tabeli 1

\begin{tabular}{|c|c|}
\hline AUtOR & DefinIIJA \\
\hline S. D. Krasner & $\begin{array}{l}\text { - suwerenność jako poziom kontroli sprawowanej przez instytucje publiczne oraz sposób lokalizacji wła- } \\
\text { dzy w ramach zakreślonych terytorialnie granic, } \\
\text { - suwerenność utożsamiana jest z poziomem kontroli sprawowanej przez władze publiczne nad trans- } \\
\text { granicznym przepływem towarów, kapitału, osób i idei, } \\
\text { - suwerenność rozumiana jest jako prawo pewnych podmiotów do zawierania porozumień międzynaro- } \\
\text { dowych (suwerenne państwa mogą zawierać traktaty) }\end{array}$ \\
\hline
\end{tabular}

Źródło: A. Hnatyszyn-Dzikowska, Realizacja stabilizacyjnej funkcji państwa w warunkach europejskiej integracji gospodarczej, Wyd. PWSZ w Pile, Piła 2009, s. 38.

Odnosząc pojęcie suwerenności do praw suwerennych przysługujących państwu bezpośrednio w zakresie kwestii gospodarczych, można określić treść suwerenności ekonomicznej, chociaż zazwyczaj nie podaje się definicji tego pojęcia ${ }^{22}$. Suwerenność gospodarcza państwa jest istotnym czynnikiem, który decyduje o możliwościach realizowania przez dany kraj jego zadań. Na płaszczyźnie stabilizacji gospodarczej za atrybuty suwerenności państwa należy uznać samodzielność prowadzenia i określenia polityki gospodarczej, tj. wyboru celów i narzędzi ich realizacji. W warunkach umiędzynarodawiania procesów gospodarczych państwa narodowe stopniowo tracą suwerenne kompetencje na rzecz współdecydowania nie tylko $\mathrm{z}$ innymi państwami, ale również $\mathrm{z}$ rozmaitymi instytucjami poziomu ponadnarodowego i samorządowego. Państwa delegują swoje uprawnienia do innych podmiotów i jedynie współdecydują w sprawach dotąd zastrzeżonych wyłącznie do ich kompetencji ${ }^{23}$. R. Keohane zauważa, iż państwa, które są członkami Unii Europejskiej, ostro zerwały z klasyczną koncepcją suwerenności. Suwerenność została połączona (pooled) w takim sensie, że wiele obszarów władzy państwowej w stosunkach wewnętrznych i zewnętrznych zostało w całości przetransferowanych na szczebel ponadnarodowy ${ }^{24}$.

Realizując stabilizacyjną funkcję państwa, rząd i bank centralny wykorzystują przede wszystkim dyskrecjonalne narzędzia polityki fiskalnej i monetarnej oraz tzw. automatyczne stabilizatory w celu zapewnienia równowagi w skali makroekonomicznej. W warunkach europejskiej integracji gospodarczej decyzje państwa odnośnie do zakresu i celu wykorzystania wymienionych narzędzi zostały stopniowo ograniczone. Proces ten odbywał się stopniowo, można więc uznać, że im wyższy stopień integracji, tym niższy poziom suwerenności gospodarczej.

22 M. Guzek, Integracja gospodarcza a suwerennośc państwa, „Sprawy Międzynarodowe” 1976, nr 12, s. 27.

${ }_{23}$ T. G. Grosse, Integracja europejska w teorii i praktyce, „Polska w Europie” 2003, nr 43, s. 23-24.

24 R. O. Keohane, Ironies of Sovereignty: The European Union and the United States, "Journal of Common Market Studies" 2002, vol. 40, no. 4, s. 748. 
Stopień i zakres przekazywania kompetencji na szczebel ponadnarodowy, jak wskazuje historia integracji europejskiej, regulowany był postanowieniami traktatowymi. Wyrazem tego jest coraz ściślejsza koordynacja polityki fiskalnej i centralizacja polityki pieniężnej.

\section{KOORDYNACJA POLITYKI FISKALNEJ}

Utworzenie w pełni funkcjonującego, jednolitego, zintegrowanego rynku europejskiego wymusza ściślejszą współpracę w zakresie polityki makroekonomicznej, zwłaszcza polityki budżetowej. Współpraca ta rozwija się na dwóch płaszczyznach: pomiędzy państwami członkowskimi (koordynacja horyzontalna) oraz między szczeblem państwowym i ponadnarodowym (koordynacja wertykalna). Głównym celem podejmowanych działań jest redukcja ryzyka niezsynchronizowanych polityk stabilizacyjnych oraz ukierunkowanie narodowych polityk fiskalnych w kierunku zbieżnych celów za pomocą wielostronnego mechanizmu nadzoru ${ }^{25}$. Rozwiązanie to jest znaczącym odchyleniem od teoretycznego modelu federalizmu fiskalnego, który zakładał przypisanie odpowiedzialności za politykę stabilizacyjną na najwyższy poziom rządu. Doświadczenie Europy różni się od większości poglądów w literaturze tym, iż nie skupia się przede wszystkim na transferze bezpośredniego zarządzania polityką stabilizacyjną na szczebel wyższy. Odpowiedzialność ta jest pozostawiona państwom członkowskim, chociaż faktyczna koordynacja zagwarantowana jest przez szczebel ponadnarodowy.

W tym kontekście szczebel ponadnarodowy odpowiedzialny jest za monitorowanie sytuacji budżetowej krajów członkowskich. Zadaniem instytucji ponadnarodowych jest identyfikacja poważnych błędów, które mogłyby stanowić źródło problemów budżetowych, a także dokonywanie oceny tej sytuacji. W odniesieniu do argumentów natury ekonomicznej najważniejsze znaczenie ma tu minimalizowanie negatywnego wpływu deficytu budżetowego na stopy procentowe w całym zintegrowanym obszarze, jak również kwestia prowadzenia zbyt ekspansywnej polityki budżetowej, która mogłaby wywierać niekorzystny wpływ na ceny - a w konsekwencji mogłaby wywołać destabilizację makroekonomiczną w poszczególnych państwach członkowskich, jak i całej Unii ${ }^{26}$. W tym kontekście należy zwrócić uwagę na słabości instytucji ponadnarodowych, które ograniczają skuteczność koordynacji. Wynika to przede wszystkim z politycznego uzależnienia od państw członkowskich. Ponadto barierą są problemy z szybkim podejmowaniem decyzji,

25 A. Majocchi, Fiscal Policy Coordination in the European Union and the Financing of the Community Budget, „SSI Working Paper” 2003, no. 1, s. 6.

${ }_{26}$ J. Ciak, Wypetnianie finansowych wymogów Traktatu z Maastricht przez kraje obszaru euro i Polskę w realizowanej polityce budżetowej, „Bank i Kredyt” 2003, nr 8, s. 31. 
które są związane z koniecznością pogodzenia stanowisk państw członkowskich. Wreszcie, instytucje ponadnarodowe mogą też dysponować stosunkowo słabym instrumentarium do realizacji powierzonych zadań, w tym sankcji, których są w stanie realnie użyć, aby wyegzekwować realizację swoich decyzji ${ }^{27}$.

Mając na uwadze powyższe słabości szczebla ponadnarodowego, uzupełnieniem ram instytucjonalnych polityki fiskalnej na szczeblu unijnym powinno być wzmocnienie krajowych instytucji budżetowych przez przyjęcie zasad fiskalnych zakładających dyscyplinę w wydatkowaniu środków oraz ich efektywność na wszystkich poziomach władzy publicznej. Obszar wyznaczony szczeblowi państwowemu w realizacji polityki fiskalnej krajów członkowskich obszaru zintegrowanego jest wynikową połączenia ograniczeń koordynujących tę politykę w skali Unii i zwiększonych oczekiwań pod jej adresem. Zadanie to oznacza zwiększenie zakresu funkcji finansów publicznych w roli stabilizatora koniunktury, poza tradycyjnymi funkcjami alokacji i redystrybucji ${ }^{28}$. Faktem jest, iż osiąganie wyznaczonych limitów i wymogów oznacza, że tymczasowo szczebel państwowy traci autonomię i swobodę w prowadzeniu krajowej polityki budżetowej ${ }^{29}$. Wielu ekonomistów raczej pesymistycznie odnosi się do możliwości skutecznej międzynarodowej koordynacji polityki fiskalnej. Jednakże koordynacja polityki fiskalnej może być w wysokim stopniu odpowiednia w odniesieniu do pewnych aspektów strukturalnych, obejmujących reformy podatkowe (sprzyjające stronie podażowej).

\section{CENTRALIZACJA POLITYKI PIENIĘŻNEJ}

Wynikiem pogłębiania procesu integracji jest centralizacja narzędzi polityki pieniężnej na szczeblu ponadnarodowym. W tym kontekście szczebel ponadnarodowy wyznacza cele, strategie i bierze odpowiedzialność za ich realizację i ma wyłączne prawo do ustalania optymalnych instrumentów polityki monetarnej. Wyznaczony cel jest wspólny dla całego obszaru zintegrowanego, a decyzje szczebla ponadnarodowego wspierają także pozostałe obszary stabilizacji makroekonomicznej, które pozostają jako przedmiot wspólnego zainteresowania wszystkich

27 K. Szeląg, Polityka gospodarcza w strefie euro: koordynacja czy centralizacja?, „Bank i Kredyt” 2004, nr 5, s. 30.

28 D. Gotz-Kozierkiewicz, Polityka fiskalna w Polsce z perspektywy cztonkostwa w Unii Europejskiej, „Ekonomista” 2004, nr 6, s. 772.

${ }_{29}$ Wskazują na to: Ch. Bean, Economic and Monetary Union in Europe, "Journal of Economic Perspectives" 1992, no. 6; W. Buiter, G. Corsetti, N. Roubini, Excessive Deficits, Sense and Nonsense in the Treaty of Maastricht, „CEPR Discussion Paper” 1992, no. 750; R. Dornbusch, Fiscal Aspects of Monetary Integration, „American Economic Review” 1997, vol. 87, no. 2. Cytat: P. Młodkowski, Konwergencja fiskalna w uniach walutowych w Afryce na tle rozwiquań europejskich, „Gospodarka Narodowa" 2006 , nr $1-2$, s. 21. 
państw członkowskich. Dla prowadzenia jednolitej polityki pieniężnej na całym obszarze Unii instytucje ponadnarodowe mają zapewnioną niezależność od rządów i możliwość swobodnego operowania klasycznymi narzędziami banku centralnego. Ponadto mają zagwarantowaną niezależność personalną swoich władz od władz poszczególnych państw i władz Unii.

Równolegle, w wyniku centralizacji polityki pieniężnej, szczebel państwowy zostaje pozbawiony kompetencji decyzyjnych z zakresu wyboru instrumentów i prowadzenia polityki monetarnej - jednakże państwa członkowskie mogą nadal wyrażać swoje opinie ${ }^{30}$. Krajowe banki centralne są ponadto w pełni włączone $\mathrm{w}$ proces decyzyjny. Podążając za instrukcjami instytucji ponadnarodowej, dbają również o wdrażanie podjętych decyzji na krajowych rynkach pieniężnych. Praktyczna realizacja postanowień szczebla ponadnarodowego i realizacja operacji z krajowymi bankami komercyjnymi jest zgodna z zasadą subsydiarności.

\section{POLITYKA STABILIZACYJNA W RAMACH SYSTEMU Z BRETTON WOODS IEUROPEJSKIEGO SYSTEMU WALUTOWEGO}

Kryzys ekonomiczny przełomu lat 20. i 30. XX wieku doprowadził do powstania znacznego bezrobocia w gospodarce światowej. W obliczu narastania nierównowagi wewnętrznej poszczególne państwa zaczęły stosować klasyczną politykę „zubożenia sąsiada”. Fala konkurencyjnych dewaluacji oraz silna polityka protekcjonistyczna nabrały jednak charakteru wojen celnych i w dużej mierze przyczyniły się do destabilizacji wymiany międzynarodowej. Ponadto napięcia polityczne w Europie, nasilające się w latach 30., oraz coraz bardziej izolacjonistyczna polityka Stanów Zjednoczonych skutecznie blokowały współpracę międzynarodową w zakresie stabilizacji kursów walutowych. Wybuch II wojny światowej ostatecznie zablokował na kilka lat próby podjęcia takiej wspólpracy.

Latem 1944 roku w miejscowości Bretton Woods (USA) przedstawiciele czterdziestu czterech państw (tzw. państwa alianckie) podpisali układ, zwany systemem z Bretton Woods (SBW) ${ }^{31}$. Głównym jego celem było uporządkowanie i ustabilizowanie sytuacji $\mathrm{w}$ handlu międzynarodowym ${ }^{32}$. SBW wprowadzal

30 K. Gawlikowska-Huecker, A. Zielińska-Głębocka, Integracja europejska od jednolitego rynku do unii walutowej, Wyd. C. H. Beck, Warszawa 2004, s. 274.

31 Opis systemu z Bretton Woods zob. m.in. A. J. Klawe, A. Makać, Zarys międzynarodowych stosunków ekonomicznych, PWN, Warszawa 1981, s. 58-69; P. R. Krugman, M. Obstfeld, Międzynarodowe stosunki gospodarcze, t. 2, PWN, Warszawa 1997, s. 217-236.

32 Szerzej na temat funkcjonowania systemu z Bretton Woods zob. S. Zwierzchlewski, Unie gospodarcze - ich powstawanie oraz przyczyny destabilizacji, Optimum. Studia ekonomiczne nr 2, Wydawnictwo Uniwersytetu w Białymstoku, Białystok 2008. 
pomiędzy państwami (uczestnikami układu) system stałego kursu walutowego oparty na tzw. centrum rezerwowym. Waluty uczestników systemu powiązano sztywnym kursem $\mathrm{z}$ dolarem amerykańskim $\mathrm{w}$ dopuszczalnym wąskim korytarzu walutowym wynoszącym 2\% (kursy poszczególnych walut w stosunku do dolara mogły się wahać jedynie w przedziale $\pm 1 \%$ od wyznaczonego parytetu). Oznaczało to, iż Stany Zjednoczone przyjęły funkcję lidera, a dolar amerykański stał się walutą rezerwową systemu.

Podstawową zaletą SBW było więc dążenie do uzyskania jak największych korzyści z wymiany międzynarodowej przez likwidację konkurencyjnych deprecjacji walut oraz barier protekcjonistycznych. Zaletą SBW było także dążenie do zwiększenia wiarygodności polityki antyinflacyjnej. Czynnikiem zwiększającym tę wiarygodność miały być właśnie sztywne kursy walutowe pomiędzy uczestnikami systemu. Wydaje się, że politycy gospodarczy wierzyli wówczas $\mathrm{w}$ to, że zarówno usunięcie barier w wymianie międzynarodowej, jak i niedopuszczenie do częstych ruchów poziomu cen w gospodarce światowej może być skutecznym pasem transmisyjnym dla zachowania pełnego zatrudnienia (lub przynajmniej dla zachowania niedużej nierównowagi wewnętrznej w obszarze zatrudnienia) w poszczególnych państwach - uczestnikach SBW.

Zasadniczą wadą omawianego systemu była jego asymetria. Wskazano już, iż podstawą funkcjonowania SBW było powiązanie kursów walut $\mathrm{z}$ dolarem amerykańskim. Dawało to Stanom Zjednoczonym (centrum rezerwowemu) wyraźnie uprzywilejowaną pozycję, ponieważ mogły one, emitując walutę rezerwową, swobodnie dobierać i ustalać wartości narzędzi gospodarczych w zależności od stanu koniunktury. Politycy mieli jednak duże zaufanie co do tego, iż Stany Zjednoczone wezmą na siebie odpowiedzialność za stabilność systemu. Liczono na to, że centrum w systemie nie będzie prowadziło destabilizującej polityki makroekonomicznej, a ewentualne zmiany tej polityki będą miały jedynie charakter czasowy. Zakładano ponadto, że nawet gdyby Stany Zjednoczone zdecydowały się na trwałą zmianę wartości podstawowych narzędzi gospodarczych (a więc wariant najbardziej pesymistyczny dla stabilności systemu), to pozostałe kraje bezwzględnie dopasują się do takiej polityki. Rzeczywistość okazała się zupełnie inna. Co prawda, przez pierwsze dwadzieścia lat SBW funkcjonował w zasadzie zgodnie z założeniami jego twórców. Od połowy lat 60. jednak destabilizacja systemu stawała się faktem. Wynikało to $z$ dwóch zasadniczych przyczyn.

Pierwszą przyczyną była zbyt ekspansywna polityka gospodarcza Stanów Zjednoczonych $\mathrm{w}$ drugiej połowie lat 60., prowadzona zarówno przez rząd, jak i bank centralny ${ }^{33}$. Wynikający z tego wzrost inflacji amerykańskiej zmusił pozo-

33 Ekspansja polityki fiskalnej wynikała przede wszystkim ze wzrostu wydatków militarnych na skutek większego zaangażowania się Stanów Zjednoczonych w konflikt wietnamski oraz wzro- 
stałe kraje systemu do podjęcia interwencji walutowych polegających na zakupie waluty rezerwowej (a w rezultacie na zakupie amerykańskich papierów wartościowych), aby przeciwdziałać presji aprecjacyjnej swoich walut wobec dolara. Skutkiem tego było powiększenie podaży pieniądza i wzrost inflacji w tych krajach. $Z$ biegiem czasu coraz bardziej rósł opór zagranicznych polityków do biernego dostosowywania się do inflacyjnej polityki Stanów Zjednoczonych. Drugą przyczyną rozpadu SBW były narastające od drugiej połowy lat 50. problemy z utrzymaniem równowagi w bilansie płatniczym centrum rezerwowego. Wynikało to z pogorszenia konkurencyjności wyrobów amerykańskich na rynku europejskim oraz wzmożonego wywozu kapitału amerykańskiego do Europy. Nie bez znaczenia była również nadmiernie ekspansywna polityka pieniężna i fiskalna Stanów Zjednoczonych, której zewnętrznym przejawem był powiększający się deficyt w płatnościach bieżących. Utrzymująca się nierównowaga zewnętrzna centrum rezerwowego coraz bardziej skłaniała amerykańskich polityków do porzucenia polityki stałych kursów walutowych opartej na stabilnej sile nabywczej dolara. Ratunkiem dla rosnącego deficytu w bilansie płatniczym miała być bowiem dewaluacja dolara wobec pozostałych walut.

W 1971 roku zdewaluowano dolara oraz dokonano rewaluacji większości pozostałych walut systemu. Kolejna dewaluacja dolara w 1973 roku ostatecznie zakończyła funkcjonowanie SBW. Po nieudanej próbie rekonstrukcji SBW, w 1979 roku powołano Europejski System Walutowy (ESW). ESW, podobnie jak SBW, oparty był na walucie rezerwowej, z tym że funkcję tej rezerwy pełniła marka niemiecka ${ }^{34}$. Kursy poszczególnych walut mogły wahać się w stosunku do waluty niemieckiej w przedziale $\pm 2,25 \%$. Uznanie marki za walutę kluczową wynikało ze szczególnej roli Bundesbanku w europejskiej bankowości centralnej. Przede wszystkim należy wskazać na stosowanie przez bank centralny Niemiec wysokich standardów informacyjnych już w pierwszej połowie lat 70. XX wieku, szczególnie w odniesieniu do stopy wzrostu podaży pieniądza. Ponadto Bundesbank był znany ze swojej wysokiej skuteczności w zwalczaniu inflacji.

Zalety i wady ESW podobne były do tych, które charakteryzowały SBW. Główną zaletą ESW była eliminacja zniekształceń kierunków wymiany międzynarodowej, m.in. przez konkurencyjne deprecjacje walut. Zasadniczą wadą omawianego systemu była wbudowana asymetria ze względu na istnienie centrum rezerwowego. Niemiecka polityka gospodarcza stanowiła punkt odniesienia dla

stu wydatków rządowych w związku z wprowadzeniem programu „Wielkie społeczeństwo”, którego celem było zwiększenie nakładów na edukacje publiczną i przebudowę miast. Natomiast polityka amerykańskiego banku centralnego nastawiona na obniżkę stóp rynkowych wynikała z negatywnych efektów restrykcji pieniężnej głównie dla branży budowlanej.

34 Szerzej na temat ESW zob. P. De Grauwe, Unia walutowa, Polskie Wydawnictwo Ekonomiczne, Warszawa 2003, s. 107-140. 
sposobu wyznaczania polityk ekonomicznych w innych krajach uczestniczących w systemie. W latach 80. udało się w zasadzie utrzymać kursy walut państw należących do ESW w wyznaczonym przedziale. Dopiero przemiany polityczne w Europie przełomu lat 80. i 90., w tym zwłaszcza zjednoczenie Niemiec, dały początek fali kryzysów w ESW. Powstanie jednego państwa niemieckiego oznaczało znaczne zwiększenie wydatków budżetu RFN, związane z kosztami restrukturyzacji gospodarki byłej NRD. Wywołana w ten sposób ekspansja fiskalna spotkała się z natychmiastową reakcją Bundesbanku. Chcąc przeciwdziałać presji inflacyjnej i jednocześnie nie osłabić swojej wiarygodności, bank centralny Niemiec zaostrzył politykę pieniężną. Taka kombinacja polityki makroekonomicznej, czyli jednoczesna ekspansja fiskalna i restrykcja pieniężna, uruchomiła presję aprecjacyjną marki niemieckiej. Pozostałe kraje ESW stanęły więc przed koniecznością podniesienia stóp procentowych, aby nie dopuścić do spadku wartości swych walut wobec waluty rezerwowej. Oznaczało to zgodę polityków gospodarczych na wystąpienie efektów recesyjnych w tych gospodarkach. Nie chcąc podtrzymywać kursu walutowego za cenę spadku produktu krajowego, niektóre państwa, m.in. Wielka Brytania i Włochy, zrezygnowały z uczestnictwa w ESW w 1992 roku i zdeprecjonowały swoje waluty ${ }^{35}$. Na skutek tych wydarzeń w sierpniu 1993 roku podjęto decyzję o znacznym rozszerzeniu dopuszczalnego poziomu wahań kursów poszczególnych walut w odniesieniu do marki niemieckiej do poziomu $\pm 15 \%{ }^{36}$. W zasadzie oznaczało to przejście na tzw. administracyjny kurs płynny. Należało to traktować jako rozwiązanie przejściowe - do czasu powołania pełnej unii walutowej w Europie.

Wskazano, iż SBW i ESW były systemami asymetrycznymi, w których jedno państwo (odpowiednio Stany Zjednoczone i Niemcy) posiadało szczególną pozycję. Oprócz tej cechy, podstawą funkcjonowania omawianych systemów była koordynacja horyzontalna ${ }^{37}$. Taki instytucjonalny układ stwarzał specyficzne warunki do prowadzenia polityki stabilizacyjnej w warunkach integracji gospodarczej. Okazało się, że asymetria systemu i współpraca oparta tylko na koordynacji

35 Szerzej na temat konsekwencji kryzysów w ESW zob. A. Sławiński, Kryzysy walutowe a kierunki międzynarodowego systemu finansowego, „Bank i Kredyt”, lipiec-sierpień 2000.

36 Znaczne rozszerzenie dopuszczalnego poziomu wahań wokół marki niemieckiej wynikało nie tylko z wycofania się Wielkiej Brytanii i Włoch z ESW. Spekulanci walutowi uznali bowiem, że także inne kraje systemu nie będą chciały dopuścić do dużego spadku produktu krajowego i będą skłonne odstąpić od utrzymywania stałych relacji kursowych. Doprowadziło to do ataków spekulacyjnych, które dotknęły m.in. franka francuskiego, pesetę hiszpańską, franka belgijskiego oraz koronę duńską.

37 Należy zaznaczyć, że EWS obejmował kraje należące do Wspólnoty Europejskiej, w której istniał budżet ponadnarodowy. Rola tego budżetu dla gospodarki Wspólnoty w latach 80 . była jednak całkowicie marginalna. 
horyzontalnej nie sprzyja stabilności systemu. Był to podstawowy wniosek, którym kierowano się przy konstruowaniu Europejskiej Unii Walutowej (EUW) ${ }^{38}$.

\section{ZAKOŃCZENIE}

Procesy integracyjne spowodowały konieczność umiędzynarodowienia interwencjonizmu państwowego. Fakt ten wpływa na zmianę charakteru stabilizacyjnej funkcji państwa - w kontekście przede wszystkim celów i narzędzi realizacji. Kompetencje w tym zakresie mogą być rozdzielone na szczebel państwowy i ponadnarodowy, w zależności od instytucjonalnych form współpracy, tzn. koordynacji lub centralizacji różnych dziedzin polityki. Obie formy ograniczają znacząco suwerenność ekonomiczną integrujących się państw. $Z$ tego względu można przyjąć, że niezbędnym początkowym warunkiem rozwoju procesów scaleniowych jest konsensus polityczny. Kolejnym warunkiem jest natomiast podporządkowanie sposobu prowadzenia krajowej polityki ekonomicznej, w tym głównie polityki stabilizacyjnej, do wymagań ugrupowania integracyjnego ogółem. Doświadczenia związane $\mathrm{z}$ funkcjonowaniem systemów integracyjnych $\mathrm{w}$ XX wieku wykazały jednak, iż trudno wypełnić ten warunek, szczególnie w systemach opartych na centrum rezerwowym. Zarówno Stany Zjednoczone w SBW, jak i Niemcy w ESW zaczęły przedkładać interes własny nad interes danego systemu, kiedy tylko wymagały tego uwarunkowania gospodarcze w tych krajach. Skutkiem tego pozostałe państwa należące do SBW lub ESW były zmuszone „importować” z centrum rezerwowego politykę inflacyjną lub recesyjną, co ewidentnie obniżało stabilność wskazanych systemów. Te doświadczenia wykorzystano przy tworzeniu EUW. Uznano bowiem, że polityka stabilizacyjna w EUW będzie wykazywała mniejsze zakłócenia w sytuacji, kiedy pojawi się element koordynacji horyzontalnej oraz koordynacji wertykalnej, a obszar jednowalutowy w Europie będzie formą integracyjną o charakterze symetrycznym.

\section{BIBLIOGRAFIA}

Antonowicz L., Pojęcie państwa w prawie międzynarodowym, Wyd. PWN, Warszawa 1974. Aron A., Problems of European Integration, „Lloyds Bank Review” 1953, no. 28.

Balassa B., The Theory of Economic Integration, Allen \& Unwin, London 1962.

Bieleń S., Suwerennośćpaństw i integracja europejska - wptywy i zależności, [w:] G. Michałowska (red.), Integracja europejska - Instytucje - Polityka - Prawo, Warszawa 2003.

38 S. Zwierzchlewski, Przysztość strefy euro, „Gazeta Bankowa” 2007, nr 47. 
Caporaso J., The European Union and Forms of State: Westpahalian, Regulatory or Post-Modern?, „Journal of Common Market Studies” 1996, no. 1.

Ciak J., Wypetnianie finansowych wymogów Traktatu z Maastricht przez kraje obszaru euro i Polskę w realizowanej polityce budżetowej, „Bank i Kredyt” 2003, nr 8.

Czaputowicz J., Rola państwa w Unii Europejskiej, Centrum Europejskie Natolin, EUI Research Laboratory, z. 11, Warszawa 2004.

De Grauwe P., Unia walutowa, Polskie Wydawnictwo Ekonomiczne, Warszawa 2003.

Gawlikowska-Huecker K., Zielińska-Głębocka A., Integracja europejska od jednolitego rynku do unii walutowej, Wyd. C. H. Beck, Warszawa 2004.

Gawłowicz I., Nowe wykorzystywanie suwerenności jako signum temporis, [w:] I. Gawłowicz, I. Wierzchowiecka (red.), Koncepcje suwerenności: zbiór studiów, Wyd. LexisNexis, Warszawa 2005.

Gotz-Kozierkiewicz D., Polityka fiskalna w Polsce z perspektywy członkostwa w Unii Europejskiej, „Ekonomista” 2004, nr 6.

Grosse T. G., Integracja europejska w teorii i praktyce, „Polska w Europie”2003, nr 43.

Grubel H. G., International Economics, Irwin, Homewood, Illinois 1981.

Guzek M., Integracja gospodarcza a suwerennośćpaństwa, ,Sprawy Międzynarodowe”1976, nr 12.

Hnatyszyn-Dzikowska A., Realizacja stabilizacyjnej funkcji państwa w warunkach europejskiej integracji gospodarczej, Wyd. PWSZ w Pile, Piła 2009.

Keohane R. O., Ironies of Sovereignty: The European Union and the United States, "Journal of Common Market Studies" 2002, vol. 40, no. 4.

Klawe A. J., Makać A., Zarys międzynarodowych stosunków ekonomicznych, PWN, Warszawa 1981.

Krugman P. R., Obstfeld M., Międzynarodowe stosunki gospodarcze, t. 2, PWN, Warszawa 1997.

Kukliński A., O przysztości państwa, [w:] Przysztość państwa a gospodarka: studia nad możliwymi kierunkami zmian roli państwa w gospodarce w przysztości, Polska Akademia Nauk, Komitet Prognoz „Polska w XXI wieku”, Wyd. Elipsa, Warszawa 1997.

Lis S., Miklaszewski S., Kraje europejskie wobec wspótczesnych procesów integracyjnych, Wydawnictwo i Drukarnia „Secesja”, Kraków 1993.

Machlup F., Integracja gospodarcza - narodziny i rozwój idei, Państwowe Wydawnictwo Naukowe, Warszawa 1986.

Majocchi A., Fiscal Policy Coordination in the European Union and the Financing of the Community Budget, „SSI Working Paper” 2003, no. 1.

Markowski K., Rola państwa w gospodarce rynkowej, Wyd. PWE, Warszawa 1992.

Marques-Mendes A. J., Economic Integration and Growth in Europe, Croom Helm, London 1986.

Marszałek A. (red.), Integracja europejska: podręcznik akademicki, Wyd. PWE, Warszawa 2004.

Młodkowski P., Konwergencja fiskalna w uniach walutowych w Afryce na tle rozwiazań europejskich, „Gospodarka Narodowa” 2006, nr 1-2.

Robson P., The Economics of International Integration, Allen \& Unwin, London 1987. 
Sławiński A., Kryzysy walutowe a kierunki międzynarodowego systemu finansowego, „Bank i Kredyt”, lipiec-sierpień 2000.

Szeląg K., Polityka gospodarcza w strefie euro: koordynacja czy centralizacja?, „Bank i Kredyt” 2004, nr 5.

Tinbergen J., International Economic Integration, Elsevier, Amsterdam 1954.

Waever O., Identity, Integration and Security: Solving the Sovereignty Puzzle in E.U., „Journal of International Affairs" 1995, vol. 48, no. 2.

Woś J., Hnatyszyn-Dzikowska A., Koncepcje suwerenności państwa w sferze polityki gospodarczej w warunkach europejskiej integracji gospodarczej, „Ruch Prawniczy, Ekonomiczny i Socjologiczny" 2007, z. 1.

Zwierzchlewski S., Przysztość strefy euro, „Gazeta Bankowa” 2007, nr 47.

Zwierzchlewski S., Unie gospodarcze - ich powstawanie oraz przyczyny destabilizacji, Optimum. Studia ekonomiczne, nr 2, Wydawnictwo Uniwersytetu w Białymstoku, Białystok 2008.

\section{STRESZCZENIE}

Procesy integracyjne spowodowały konieczność umiędzynarodowienia interwencjonizmu państwowego. Fakt ten wpływa na zmianę charakteru stabilizacyjnej funkcji państwa w kontekście przede wszystkim celów i narzędzi realizacji. Kompetencje w tym zakresie moga być rozdzielone na szczebel państwowy i ponadnarodowy, w zależności od instytucjonalnych form współpracy, tzn. koordynacji lub centralizacji różnych dziedzin polityki. Obie formy ograniczają znacząco suwerenność ekonomiczną integrujących się państw. $Z$ tego względu można przyjąć, że niezbędnym początkowym warunkiem rozwoju procesów scaleniowych jest konsensus polityczny. Kolejnym warunkiem jest natomiast podporządkowanie sposobu prowadzenia krajowej polityki ekonomicznej, w tym głównie polityki stabilizacyjnej, wymaganiom ugrupowania integracyjnego ogółem. Doświadczenia związane $\mathrm{z}$ funkcjonowaniem systemów integracyjnych w XX wieku wykazały jednak, iż trudno wypełnić ten warunek, szczególnie w systemach opartych na centrum rezerwowym. Zarówno Stany Zjednoczone w SBW, jak i Niemcy w ESW zaczęły przedkładać interes własny nad interes danego systemu, kiedy tylko wymagały tego uwarunkowania gospodarcze w tych krajach. Skutkiem tego pozostałe państwa należące do SBW lub ESW były zmuszone „importować” z centrum rezerwowego politykę inflacyjną lub recesyjną, co ewidentnie obniżało stabilność wskazanych systemów. Te doświadczenia wykorzystano przy tworzeniu EUW. Uznano bowiem, że polityka stabilizacyjna w EUW będzie wykazywała mniejsze zakłócenia w sytuacji, kiedy pojawi się element koordynacji horyzontalnej oraz koordynacji wertykalnej, a obszar jednowalutowy w Europie będzie formą integracyjną o charakterze symetrycznym. 


\title{
THE STABILIZING FUNCTION OF THE STATE IN THE CONDITIONS OF INTERNATIONAL ECONOMIC INTEGRATION: AN HISTORICAL OUTLINE
}

\author{
SUMMARY
}

The advancing process of international economic integration has given rise to a discussion over the broadly understood costs of such a process. The main area of this discussion is the scope of the loss of economic sovereignty in the countries implementing various forms of integration. Such countries have to conform to some extent their method of defining their economic policy, including their stabilization policy, in accordance with the requirements of a given form of integration. However, drawing on the experiences of various integration groups in the $20^{\text {th }}$ century, it may be concluded that it is difficult to maintain discipline in the manner of conducting the stabilization policy in times when one's own economy requires immediate changes in the monetary and fiscal sphere. 
